\begin{tabular}{c} 
Volume and Issues Obtainable at Center for Sustainability Research and Consultancy \\
Sustainable Business and Society in Emerging Economies \\
ISSN: $2708-2172$ \& (E): 2708-2504 \\
Volume 3: Issue 3 September 2021 \\
CSRᄃ \\
Journal homepage: $\underline{\text { www.publishing.globalcsrc.org/sbsee }}$ \\
\hline
\end{tabular}

\title{
Provision of Technical and Vocational Education and Training to Needy Youth in Punjab: An Explanatory Study
}

*Dur-e-Nayab, Institute of Education and Research, University of the Punjab, Lahore, Pakistan Abid Hussain Ch., Institute of Education and Research, University of the Punjab, Lahore, Pakistan Ghulam Fatima, Institute of Special Education, University of the Punjab, Lahore, Pakistan

*Corresponding author's email address: durenayab18@yahoo.com

\begin{tabular}{l}
\hline ARTICLE DETAILS \\
\hline History \\
Revised format: Aug 2021 \\
Available Online: Sep 2021 \\
\hline Keywords \\
Technical and Vocational \\
Education, Needy youth \\
Strengths, Weaknesses \\
Punjab Vocational Training \\
Council.
\end{tabular}

JEL Classification

120,124

\section{OPEN ACCESS}

\section{ABSTRACT}

Purpose: The main focus of the study was to explain the perspective of the principals of Vocational Training Institutions (VTIs) on the provision of Technical and Vocational Education and Training (TVET) to deprived and needy youth. These institutions are being run by Punjab Vocational Training Council (PVTC). This paper is an intellectual effort to search out the strengths and weaknesses of TVET program and to find out the actual needs of the institutes for providing quality technical and vocational education.

Design/Methodology/Approach: The study was qualitative in nature. An in depth interview schedule, validated by a panel of three experts, was designed to collect data. The population of the study consisted of all 208 principals working in VTIs in Punjab. The sample of study consisted of 20 principals ( $10 \%$ of the population) who were randomly selected from all the institutes of Punjab.

Findings: Results revealed that TVET is an effective tool for imparting skills to the deprived and needy youth which enables them to live their lives with prosperity and dignity. Additionally, it is an important factor to alleviate poverty. On the other hand, TVET program is lacking in provision of latest equipment, trained and sufficient staff and demand driven skills.

Implications/Originality/Value: The study will be beneficial to policy makers, provincial government and the authorities of Punjab Vocational Training Council.

(C) 2021 The authors, under a Creative Commons AttributionNonCommercial- 4.0

Recommended citation: Nayab, D., Chaudhary, A. H. and Fatima, G. (2021). Provision of Technical and Vocational Education and Training to Needy Youth in Punjab: An Explanatory Study. Sustainable Business and Society in Emerging Economies, 3 (3), 265-272.

\section{Introduction}

Technical and Vocational Education and Training (TVET), also called Vocational Training and Career and Technical Education (CTE) gives employment related technical training to work in a particular profession. These projects commonly emphasize on furnishing students with practical education and can lead to a certificate or a diploma (Sarasyuen, 2020). Vocational and technical training is usually 
uninterested with content or conventional educational skills. Technical and Vocational Education and Training (TVET) courses are ordinarily more limited and more useful than higher education courses and have an industry and job centered, related with the work market. Vocational training, hence, gives a connection between education and the working world (Doak, 2019).

The Technical and Vocational Education and Training (TVET) is especially significant for encouraging financial growth, extending the scope of employment, improving the nature of work and eradicating poverty. The current social and economic improvements, vocational and technical institutes and industries' collaboration is quite possibly the best technique for professional training. Preparing the students with most advanced and demanded skills is a significant assurance for the improvement of professional training and vocational education (Moodie, 2020). In the present globalizing world, economic markets are moving from a local to an international arena. Competition in financial business sectors has gotten increasingly intense. The economic development drives the demand for employment skills and great labour force in different fields of the entire society, starting another round of improvement of vocational education. In the international market, skilled labour force is the way to economic growth and development (Cong \& Wang, 2012).

Punjab Vocational Training Council (PVTC) was set up in October 1998 by the Government of the Punjab, under the Punjab Vocational Training Council Act. This act was passed by the Punjab Assembly on September 24, 1998; consented to by the Governor of the Punjab on September 29, 1998. It is founded on public and private partnership. It is using Zakat $(2.25 \%$ of the total amount of a wealthy Muslim to be given to the needy Muslims) Funds for poverty alleviation on the principle of dole out to pay roll by providing demand driven skill and training to deserving needy youth specially Mustahaqeen-e-Zakat (deserving Muslims) at their doorstep. There are 3,634 public and private technical and vocational institutes in Pakistan, in which Punjab Vocational Training Council is running 208 vocational institutes. The number of students, who can finish their graduation from these institutes is 40,000 for every annum. This council offers various courses related to 51 trades to needy young boys and girls. The Punjab Government dispensed Rs. 400 million for Punjab Vocational Training Council (PVTC) in spending plan 2019-2020 (Lodhi, 2019).

\section{Literature Review}

Technical and Vocational Education and Training (TVET) programs give an education that help in getting a new job or work. These programs impart training on improving skills that is also called skillbased training. This training focuses on creating and applying particular skills and behaviours (Pioneer State High School, 2020). Students must spend most of their training time in learning, creating, and practicing skills in a range of real situation and environment. After completing the TVET courses and trainings, the skilled labourers can do their jobs and work independently or join any kind of industry or market. A definitive target of skills training is not just empowering the student to gain capability in the skills, yet have the confidence to expertly apply it at work (Moodie, 2020).

\section{Importance of TVET}

Technical and Vocational Education and Training is vital and essential for economic and social development. Technical and Vocational Education and Training (TVET) is seen as a tool for improving productivity and decreasing poverty. As there is a positive correlation between the proportion of TVET students at the post-secondary level and per capita income. Many nations have taken numerous steps to enforce and improve policy guidelines and governing structures for TVET and to improve associations with private sectors and employers (Shakir, 2020). However, there is a contrast between developed and developing nations as far as their main goals with respect to TVET are concerned. The developed nations accentuate quality improvement, observing and assessing TVET, the obtainability of national development plans, however, the developing countries center around the expense of enrolment and execution of TVET. Although skilled human resources are the main strength of numerous nations, an incompetent labour force is still among the most challenging factors for working together or doing 
business in numerous nations (Abdullah, 2016).

\section{Current Situation of TVET in Pakistan}

In Pakistan, TVET sector has a great strength to face the severe challenges like minimizing skills gaps and reducing joblessness. On the other hand, TVET also experiences the negative view of policy and decision makers that it is less important as compared to the general education which brought about decrease in supply of talented workforce (Shakir, 2020). Such negative insight leaves unfavourable effects on TVET sector that is considered as bad quality and yielding low returns restricting investments for skill development (Shah, 2017). Such lowering predictions, TVET institutes gradually experience the inferior infrastructure as compared to general education channels, that is why they also do not receive sufficient funds for teacher training, curriculum updates, and the equipment required for skill development (Lodhi, 2019).

In the context of Pakistan, it is believed that the current TVET system, technical education standards, curriculum and teacher training materials does not match with the growing demand of national and international jobs. Such a high concentration of private sector does not follow any minimum academic standards that results in imbalances owing to the increased supply of skilled workforce in the labor market (Khan \& Zaib, 2017).

\section{Objectives of the Study}

The following objectives were framed:

1. To collect the background information about the establishment of Punjab Vocational Training Council (PVTC) for the Technical and Vocational Education and Training program of needy youth enrolled at Vocational Training Institutes (VTIs).

2. To know the views of principals on provision of Technical and Vocational Education and Training to Needy Youth in Punjab.

\section{Research Questions}

The study was planned to answer the following questions:

1.1 What were the objectives about the establishment of Punjab Vocational Training Council for providing technical and vocational education and training to needy youth?

2.1What are the strengths and weaknesses of curriculum being implemented in Vocational Training Institutions (VTIs) of Punjab Vocational Training Council?

2.2What are the strengths and weaknesses of currently running TVET program?

2.3Which suggestions have been given by the principals of VTIs to improve the TVET program of Punjab?

\section{Methodology}

It was a qualitative study in nature and data were collected through conducting interviews of the principals of VTIs.

\section{Population}

The population of the study consisted of all 208 principals working in VTIs in Punjab.

\section{Sample}

The sample of study consisted of 20 principals (10\% of the population) who were randomly selected from all the institutes of Punjab.

\section{Instrument}

An in-depth interview schedule, validated by a panel of three experts, was designed to collect data. 


\section{Data Analysis}

Qualitative data analysis techniques were used including generating themes, making categories, coding, and reporting findings. By listening to and analyzing the responses of principals, these were transcribed, and themes were derived through thematic analysis technique.

\section{Findings}

The findings of the study are being presented as under:

\section{Q1: What were the objectives of establishing Punjab Vocational Training Council?}

To answer the first question, almost all the principals were having the same views that PVTC is utilizing Zakat Funds for poverty alleviation and by providing demand driven skill training to deserving youth, involving private sector to enhance employability and assist the graduates in their placement for permanent rehabilitation and arranging financial support for their self-employment from Micro Finance Institutions and NGOs.

\section{Q2: The students of TVET are facing the problems in life skills (honesty, team work, cooperation} etc.), what steps are being taken to improve the life skills of the students?

To answer the above question, all principals were having the same answer that improving the life skills of the students, the institute had included a book named "Life Skills and Entrepreneurship" which is a part of curriculum and mandatory with all the TVET courses. A separate teacher has been hired for teaching life skills. The institutes are trying their level best to improve the life skills of the students by using curricular and co-curricular activities. On the other hand, principals give frequent lectures to the students on the topic of life skills and teachers use different activities in the classrooms for improving the life skills of the students.

Q3: What are the strengths and weaknesses of curriculum being implemented in Vocational Training Institutions (VTIs) for teaching academics, ethics and demand driven and employable vocational skills in various trades to needy young boys and girls after passing matriculation?

According to all the principals of VTIs, PVTC has its own CRC (Curriculum Review Committee), which sends the pro forma to the principals of every institute to be filled in by the teachers after every academic year to amend the curriculum according to the need of the market but, unfortunately, all the changes are not made. As principal 1 gives the example that "when the curriculum is reviewed and changed before the new academic year and after two months some innovation is taken place in any equipment or trade, CRC does not change the curriculum at that specific time". So the curriculum is changed on its own time and during the whole year students study the old curriculum and use old equipment which was obsolete in the market.

According to the participants, following are the strengths and weaknesses of the curriculum which were stated by almost all the participants.

Table 1.1: Strengths and weaknesses of the implemented curriculum

\begin{tabular}{ll}
\hline Strengths & Weaknesses \\
\hline $\begin{array}{l}\text { The institute involves teachers for the upgradation of } \\
\text { curriculum. }\end{array}$ & $\begin{array}{l}\text { Institutes do not involve the people from industry. } \\
\text { Curriculum is very comprehensive. }\end{array}$ \\
$\begin{array}{ll}\text { PVTC does not amend the curriculum according to } \\
\text { technological advancements. }\end{array}$ \\
$\begin{array}{l}\text { Curriculum is based on } 80 \% \text { practical and } 20 \% \text { theory. } \\
\text { Curriculum is based on the demand driven skills. }\end{array}$ & $\begin{array}{l}\text { On Job Training (OJT) is only of two months. } \\
\text { Curriculum is not updated periodically. }\end{array}$ \\
\hline
\end{tabular}

\section{Q4: What type of teachers training courses are arranged for teaching to vocational students effectively?}

All the principals were having the same perspective related to different training courses. According to them, PVTC has its own institute named STTI (Staff Teacher Training Institute) which is responsible for 
conducting all types of pedagogical and skill trainings. This institute issues its calendar on the beginning of every academic year for training of different selected teachers. They have given the trainings in the field of pedagogical, technical and vocational skills. In the COVID 19 Pandemic, the trainings were not suspended instead these were shifted from traditional to online mode. They further described that many national and international trainers are invited for the trainings of teachers. Online teachers' training also has potential benefits for teachers and enable all of them to attend it.

\section{Q5: How are you going to create or provide jobs for the TVET students?}

While answering the above question, most of the principals had the same answer related to creating or providing jobs. According to them, PVTC has a separate department for Career Guidance and Job Placement which supports graduates with career related challenges through their expertise in career counseling and labour market. Admission \& Placement Officers are often capable of supporting PVTC's graduates in finding suitable placement / jobs. Admission \& Placement Officers are also responsible for arranging on job trainings for trainees in local industry. Two months On Job Training (OJT) is mandatory for every trainee before final assessment / examination.

Graduates interested in overseas employment are also guided how to seek employment abroad, how to prevent them from fraud by dealing with registered overseas employment only. Graduates are encouraged to become entrepreneurs rather than job seekers so graduates having good business plans are encouraged to apply for financial assistance through government and non-government small grants and loans to start their own businesses. On the other hand, PVTC has signed MOUs with different companies and industries. Whenever these companies need workers, they contact local VTIs to provide employees to them. Some of the principals (40\%) also stated that PVTC is lacking behind in this department. Students have to face lot of problems while doing OJT and for finding a job, but $60 \%$ students managed to get a job and survive in the industry.

\section{Q.6. Which awareness programs and vocational guidance activities are arranged for students, parents, and teachers?}

According to the principals, Admission and Placement Officers (APOs), with the help of principals are responsible for creating awareness in the society related to TVET programs. In the supervision and guidance of APOs, principals plan different strategies for the awareness of TVET. They use to print pamphlets, prepare banners, make visits to villages, give advertisements on television and in newspaper, and make announcements in mosques during admission campaign. Three to four principals also stated that their teachers also do the corner meetings and campaign in the rural areas and create awareness among people of the benefits of TVET.

\section{Q.7. What are the strengths and weaknesses of currently running TVET program?}

According to the principals working in VTIs, TVET is the most effective tool for imparting skills to the deprived and needy youth and enable them to live their lives with prosperity and dignity. It is also an important factor to alleviate poverty. They further explain that Pakistan is a developing country, so it faces a lot of financial problems in every field. There are many problems which are faced by TVET sector but the most important is equipment. As principal 7 states that "As you know that, refrigerators and air conditioners are available in the market with inverters but we don't have refrigerators and air conditioners with inverters in institutes and students are forced to practice on the obsolete equipment, this is great drawback of TVET sector". Some strengths and weaknesses of TVET program are as follows.

Table 2.1: Strengths and weaknesses of TVET program

\begin{tabular}{|c|c|}
\hline Strengths & Weaknesses \\
\hline $\begin{array}{l}\text { es. } \\
\text { with the }\end{array}$ & $\begin{array}{l}\text { ding to the market needs. } \\
\text { de. }\end{array}$ \\
\hline the training of faculty by & re also being taught \\
\hline
\end{tabular}


Curriculum is based on $80 \%$ practical skills. VTIs restrict students to follow strict discipline. $80 \%$ attendance is compulsory in institutes
Buildings of VTIs are not purpose built.

Equipments are not latest.

Budget is not sufficient for VTIs.

\section{Q8: Is OJT effective, which kind of behavior students have to face during OJT?}

Almost all the principals were agreed on the point that OJT is very effective. Additionally, it gives the students real working environment and enables them to learn many things related to their job. They further said that it is so much effective that its duration should be more than two months. As far as the behaviours of employers are concerned, $40 \%$ principals reported that students have to face nice and welcoming behavior whereas $60 \%$ of principals stated that students have to face the rude behavior of the employers. The main reason of the employers' impolite behavior is the incompetency of the students in managing their jobs, that is why employers consider them a burden on their industries.

\section{Q.9. What are your suggestions to improve the performance of TVET programs?}

All the principals have given the following suggestions for the improvement of TVET programs.

$>$ Trades should be updated and demand driven.

$>$ Tools should be latest.

$>$ The number of qualified staff should be increased.

$>$ Infrastructure should be improved.

$>$ Salaries should be increased.

$>$ Budget should be increased.

$>$ Obsolete trades must be removed from the list of courses.

$>$ There should be a separate institute like HEC (Higher Education Commission) to look after all the matters of TVET.

$>$ Curriculum should be modified and reviewed periodically.

$>$ Quality training should be given to teachers.

$>$ The number of qualified staff should be increased.

$>$ There should be a proper check and balance system for TVET sector.

\section{Discussion}

A good initiative taken by PVTC was to give demand driven and employable skills to needy young boys and girls by utilizing zakat funds, enabling them to earn their livelihood and be an efficient part of society. These TVET programs are also helpful in alleviating poverty (PVTC, 1998). For the success of the programs, it is very essential to update the curriculum periodically and train the teachers according to that curriculum (Gull, Hashmi \& Altaf, 2019). According to Abdullah (2016), an effective curriculum and its timely upgradation provides teachers, students, administrators and community stakeholders with a measurable plan and structure for delivering a quality education. The curriculum identifies the learning outcomes, standards and core competencies that students must demonstrate before going to the next level (Lofgren, Llomak \& Toom, 2020).Teachers play a key role in developing, implementing, assessing and modifying the curriculum. An upgraded and effective curriculum acts as a road map for teachers and students to follow the path to academic success (Raza \& Khalid, 2017).

Teacher trainings are also very important for refreshing their previous knowledge and imparting new knowledge. These trainings are really helpful for the development and grooming of teachers. These trainings also aware them of the progress of the world in their related field (Bukit, 2012). These trainings are arranged every year but data collected from the teachers show that every teacher does not get a chance to attend these trainings. These programs not only facilitate the needy youth but also play an effective role for the development and progress of the country. These programs enable students to earn their livelihood with respect and honor. These programs also make them self- reliant and confident in their daily life (Study International, 2021). So, it is need of the hour to make TVET programs efficient and effective because with the weaknesses it is not possible for any institution or organization to give 
excellent results and achieve its objectives.

\section{Recommendations}

Based on the findings of the study, it is recommended that:

$>$ The government should sufficiently fund, design, implement, and accomplish TVET programs in VTIs of Punjab.

$>$ The quality of TVET programs must be measured. This can be attained by providing adequate facilities, tools, effective teaching materials, qualified TVET staff and provision of in-service training for TVET teachers.

$>$ There should be proper supervision and monitoring of the implementation of TVET programs by government.

$>$ Labs should be properly maintained and equipped with the required technologies.

$>$ Curricula should be reviewed and revised periodically to meet the necessities of rapid technological advances.

$>$ At least one University of Technical and Vocational Education and Training (TVET) should be established in every province.

\section{References}

Doak, M. (2019).What is Vocational Training? Other Opportunities for Vocational Training. Retrieved on $2^{\text {nd }}$ Feb, 2019 from https://careers.stateuniversity.com/pages/854/Vocational-Training.html

Moodie, G. (2020). Skills for human development, transforming vocational education and training. Journal of Vocational Education \& Training,72(3),461-464.

DOI: $10.1080 / 13636820.2019 .1627065$

Sarasyuen, N, S. (2020). From vocational worker to vocational teacher: A study of identify transition and loss. Journal of Vocational Education and Training,72(3), 333-349. DOI: $10.1080 / 13636820.2019 .1607533$

Cong S., \& Wang X. (2012). A perspective on technical and vocational education and training. In D. Zeng (Eds.), Advances in computer science and engineering, Advances in intelligent and soft computing (Vol 141). Berlin: Springer

Lodhi, A. (2019). Budget allocates Rs32 billion for school education. The Express Tribune. Retrieved on $7^{\text {th }}$ Feb,2020 from https://tribune.com.pk/story/1992730/1-budget-allocates-rs32-billionschool-education/

Pioneer State High School (2020). Vocational Education and Training in schools. Retrieved from https://pioneershs.eq.edu.au/curriculum/vocational-education

Gull, M., Hashmi, A., \& Altaf, F. (2019). Teachers' perceptions about problems and prospects of Diploma of Associate Engineers (DAE) program in Punjab .Global Regional Review (GRR), 4(4), $612-620$.

DOI: 10.31703/grr.2019(IV-IV).56

Abdullah (2016). Life and career skills among TVET students in polytechnics in Malaysia. Retrieved from file://C:/Users/user/Desktop/material\%20phd/unemployment\%20and\%20life\%20skills.pdf

Bukit, M. (2012). Strengthening TVET teacher education. Retrieved from https://unevoc.unesco.org/fileadmin/user_upload/docs/Synthesis_report_eForumTVET_Teachers .pdf

Na, S. (2014). Relations between TVET system and employment. Retrieved from https://www.researchgate.net/publication/300860468_Relations_Between_TVET_System_and_ Employment/citations

(Study International, 2021). The benefits of choosing a vocational education in 2021. Retrieved from https://www.studyinternational.com/news/vocational-education-benefits-2021/

Khan, \& Zaib, M. (2017). Comparative analysis of TVET sector in Pakistan. Retrieved from 
https://www.voced.edu.au/search/site/all_creators\%3A\%22Khan\%2C\%20Mansoor\%20Zaib\%22 on 21 March 2021.

Shakir, R, A. (2020). Need for robust TVET sector. Retrieved from https://tribune.com.pk/story/2202026/need-robust-tvet-sector

Lofgren, S., Llomak, L., \& Toom, A. (2020).Employer views on upper secondary vocational graduate competencies. Journal of Vocational Education \& Training,72(3), 435-460.

DOI: $10.1080 / 13636820.2019 .1635633$

Shah, S, A. (2017). Comparative analysis of TVET Sector in Pakistan. Gesellschaft für Internationale Zusammenarbeit (GIZ). Retrieved from file://C:/Users/user/Desktop/material\%20phd/Comparative\%20Analysis\%20of\%20TVET\%20S ector\%20in\%20Pakistan.pdf 